\title{
Bercocok Tanam Hidroponik di Desa Sungsang III Kabupaten Banyuasin, Sumatera Selatan
}

\author{
Syaiful Eddy ${ }^{*}$, Andi Arif Setiawan ${ }^{2}$, Dian Mutiara ${ }^{3}$ \\ 1,2,3 Fakultas MIPA Universitas PGRI Palembang \\ E-mail: syaifuleddy@gmail.com¹, aaschem90@gmail.com², \\ dihartaa@gmail.com ${ }^{3}$ \\ *Corresponding author: syaifuleddy@gmail.com ${ }^{1}$
}

\begin{abstract}
ABSTRAK
Desa Sungsang III merupakan desa yang mayoritas masyarakatnya hidup sebagai nelayan. Kondisi lingkungan tempat tinggal berupa perairan penuh dengan sampah botol plastik. Kegiatan Pengabdian Kepada Masyarakat (PKM) ini bertujuan mengenalkan kepada masyarakat Desa Sungsang III berupa pemanfaatan limbah botol plastik sebagai tempat penanaman hidroponik. Metode pelaksanaan meliputi: survei, sosialisasi ke masyarakat, persiapan peralatan dan bahan, penanaman benih/penyemaian, pemeliharaan dan panen. Hasil dari kegiatan PKM yang telah dilakukan menunjukkan masyarakat Desa Sungsang III sudah mempunyai pengetahuan dalam pemanfaatan limbah botol plastik untuk bertanam sayuran (bayam merah, kangkung dan sawi sendok/pakcoy) dengan cara hidroponik. Masyarakat berharap agar kegiatan ini dapat dikembangkan lebih besar dengan berbagai macam sayuran.
\end{abstract}

Kata Kunci: Desa Sungsang III; hidroponik; limbah botol plastik; sayuran

\begin{abstract}
Sungsang III Village is a village whose majority of people live as fishermen. Living environment conditions in the form of waters full of plastic bottle bins. The Community Service Activities (PKM) aims to introduce the people of Sungsang III Village in the form of utilizing plastic bottle waste as a place for hydroponic planting. The method of implementation includes surveys, socialization to the community, preparation of equipment and materials, seed planting / seeding. maintenance and harvesting. . The results of the PKM activities that have been carried out show that the people of Sungsang III Village already have knowledge in the use of waste plastic bottles for growing vegetables (red spinach, kale and pakcoy) by means of hydroponics. The community hopes that this activity can be further developed with a variety of vegetables
\end{abstract}

Keyword: Sungsang III village; hydroponic; plastic bottle waste; vegetables 


\section{PENDAHULUAN}

Desa Sungsang merupakan daerah yang terletak di wilayah pesisir Pantai Timur Sumatera, yaitu tepatnya di muara Sungai Musi menuju ke Selat Bangka dengan kondisi padat penduduk, salah satunya yaitu Desa Sungsang III. Desa Sungsang III secara administrasi terletak di Kecamatan Banyuasin II, Kabupaten Banyuasin, Provinsi Sumatera Selatan. Masyarakatnya sama seperti masyarakat yang hidup di wilayah pesisir, memiliki mata pencarian sebagian besar sebagai nelayan, disamping itu ada juga yang berdagang, bertani, usaha rumah walet dan sebagai buruh harian.

Desa Sungsang III dapat dikategorikan sebagai mitra yang tidak produktif secara ekonomi/sosial, dikarenakan mayoritas mata pencarian nelayan ini tentunya hanya sangat bergantung pada kondisi cuaca, pada bulan November hingga Februari kondisi cuaca perairan gelombang besar, sehingga para nelayan tidak melaut. Kondisi ini tentunya mayoritas masyarakat nelayan tersebut kurang produktif, sehingga penghasilan yang didapatkan dari melaut bisa dikatakan tidak ada. Banyak permasalahan yang menjadi kendala dalam upaya meningkatkan produktifitas ekonomi/sosial masyarakat, baik permasalahan sosial-ekonomi, kondisi geografis maupun permasalahan regulasi. Berdasarkan hasil identifikasi permasalahanpermasalahan yang ada meliputi masalah kebersihan lingkungan, kesehatan masyarakat, kebutuhan air bersih, pendidikan, narkoba dan degradasi hutan. Letak Desa di muara Sungai Musi ini tentu mengakumulasi semua pencemar yang dibawa dari hulu aliran Sungai Musi.

Berbagai aktifitas di hulu sungai seperti industri tambang minyak, gas batubara serta stockpile batubara dapat menyebabkan pencemaran (Setiawan et al., 2018). Hal ini diperparah dengan kesadaran masyarakat untuk membuang sampah pada tempatnya masih sangat kurang terlihat sampah bertebaran di sekitar rumah warga serta tidak tersedianya tempat sampah di lingkungan sekitar ditambah lagi padatnya penduduk di daerah ini sehingga akumulasi limbah (sampah) semakin hari semakin besar. 
Wilayah Sungsang juga sangat berdekatan dengan Hutan Lindung Air Telang (HLAT). Sebagian masyarakat di sini ada yang memanfaatkan HLAT untuk berbagai kegiatan seperti berkebun kelapa, kelapa sawit, tambak serta pembangunan pelabuhan Tanjung Api-api oleh pemerintah (Eddy et al. 2017). Eddy dan Mutiara melaporkan bahwa hasil analisis menggunakan GIS (Global Information System) terjadi perubahan tutupan lahan di HLAT periode 1 (1989-2001) sekitar 55,11\% (6.978 ha) dan periode 2 (2001-2013) sekitar $\quad 44,8 \% \quad(5.671,53 \quad$ ha $)$. Kesadaran masyarakat lokal akan pentingnya peran HLAT dalam aspek ekologis secara umum masih rendah karena masyarakat masih lebih memprioritaskan mengkonversi hutan dalam pemenuhan kebutuhan ekonomi, sehingga vegetasi hutan mangrove banyak mengalami kerusakan (Eddy et al. 2019). Sjarkowi (2014) mengemukakan ada tujuh kendala dalam pengelolaan ekosistem lahan basah khususnya di pantai timur Sumatera termasuk Desa Sungsang, yaitu: 1) keterbatasan sarana dan prasarana fisik, 2) kegiatan
HPH (Hak Pengusahaan Hutan) yang kurang terkendali, 3) pendangkalan sungai yang terus meningkat, 4) kehadiran penebang liar namun terorganisir, 5) tumpang tindih alokasi lahan untuk aneka kegiatan, 6) keterancaman habitat unik yang belum memiliki sistem perlindungan yang memadai, dan 7) ketiadaan ilmu pengetahuan dan teknologi tepat guna di lahan basah. Hal ini tentu membutuhkan solusi pemecahannya yang melibatkan berbagai macam stakeholders termasuk perguruan tinggi.

Program PKM ini akan memanfaatkan limbah plastik (botol dan gelas plastik) sebagai wadah/tempat penanaman tanaman sehingga dapat mereduksi limbah plastik yang menjadi permasalahan dalam kebersihan lingkungan. Selain itu juga, penanaman tanaman secara hidroponik merupakan solusi permasalahan keterbatasan ruang akibat penduduk yang padat seperti halnya di Desa Sungsang III dan sekitarnya.

Kultur yang digunakan adalah kultur air (aquaculture). Kultur air merupakan metode menumbuhkan tanaman dengan air sebagai media 
yang dilengkapi larutan zat makanan. Kebutuhan air tawar untuk bercocok tanam mutlak dibutuhkan karena air merupakan kebutuhan esensial tanaman. Sulitnya mendapatkan air tawar di Desa Sungsang III, karena airnya payau/asin, menjadi permasalahan tersendiri dalam bercocok tanam. Melalui program hidroponik ini maka besarnya kebutuhan air tawar dapat direduksi karena sirkulasi air dapat dijaga dan dikontrol.

Terkait dengan pelaksanaan penelitian maupun pengabdian kepada masyarakat (PKM) telah banyak dilakukan para peneliti/praktisi guna meningkatkan kesejahteraan masyarakat. (Siaga \& Lakitan, 2021) melaporkan bahwa budidaya tanaman padi dan terong dapat dilakukan di lahan tergenang berupa lahan lebak dengan cara pembibitannya dilakukan dengan cara terapung. Budi daya padi dan terong tersebut agar dapat terapung dengan menggunakan botol-botol plastik bekas. Saleh et al., (2019) melakukan PKM tentang penanaman padi di lahan rawa dengan menggunakan botol bekas. Adapun tahapan yang dilakukan sosialisasi, pembuatan percontohan, pendampingan, penyuluhan dan respon para petani. Hasilnya menunjukkan respon yang positip berupa pemahaman masyarakat tentang teknologi tepat guna dalam pemanfaatan botol bekas untuk budidaya padi. Yunus et al., (2019) mengemukakan hasil PKM tentang budidaya tanaman dengan metode hidroponik dengan memanfaatkan botol plastic bekas di lingkungan guru SMPN Bantaeng. Hasil PKM menunjukkan para guruguru bertambah pengetahuan dan keterampilan dalam budidaya tanaman dengan menggunakan hidroponik.

Kusomo et al. berpendapat bahwa pengolahan produk sayuran organik jika diolah menjadi mie sayuran organik dapat meningkatkan nilai tambah dari produk sayuran tersebut. Pardian et al. (2017) mengemukakan bahwa kegiatan pengabdian pada masyarakat dalam bentuk bertanaman sayuran dapat berkontribusi dalam aspek lingkungan, sosial dan ekonomi.

Uraian tersebut diatas terlihat pentingnya dicarikan solusi bagi masyarakat Sungsang III dalam menanggulangi pendapatan 
perekonomian yang kurang akibat cuaca yang tidak bersahabat, disamping itu juga memberikan penyadaran masyarakat untuk tidak membuang sampah ke sungai.

\section{METODE PENELITIAN}

Kegiatan PKM ini dilaksanakan di Desa Sungsang III yang terletak di wilayah pesisir Pantai Timur Sumatera, yaitu tepatnya di muara Sungai Musi menuju ke Selat Bangka. Secara administratif Desa Sungsang III terletak di Kecamatan Banyuasin II, Kabupaten Banyuasin, Provinsi Sumatera Selatan, berjarak sekitar 87 km dari Kota Palembang (Gambar 1).

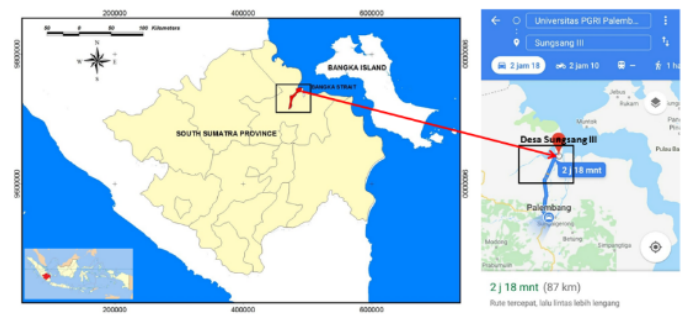

Gambar 1. lokasi Desa Sungsang (sumber: Eddy et al., 2017; Google Map, 2018).

Metode dalam kegiatan PKMS ini terbagi dalam beberapa tahapan, yaitu:

1. Survei.

Hasil survei melalui wawancara dengan masyarakat diperoleh bahwa masyarakat Desa Sungsang III umumnya memiliki tingkat ekonomi menengah ke bawah. Sebagian besar masyarakat bekerja sebagai nelayan dan mengolah produk-produk perikanan, misalnya membuat kerupuk udang, pempek udang, ebi (udang kering), ikan asin dan tekwan udang. Selain itu, sebagian masyarakat ada juga yang bekerja sebagai pedagang dan penarik becak/bentor. Masyarakat Desa Sungsang III sebagian besar memiliki tingkat pendidikan sampai Sekolah Menengah, sedangkan yang melanjutkan pendidikan ke perguruan tinggi masih sangat sedikit. Hal ini terjadi karena permasalahan biaya dan jarak yang cukup jauh untuk menjangkau perguruan tinggi.

\section{Sosialisasi}

$\begin{array}{ccc}\text { Kegiatan } & \text { sosialisasi } & \text { ke } \\ \text { masyarakat } & \text { dengan } & \text { cara }\end{array}$
mengumpulkan warga yang ada di Desa Sungsang III tersebut di Balai Desa. Isi kegiatan sosialisasi berupa mengenalkan bercocok tanam secara hidroponik, keuntungan dan manfaat bertanam secara hidroponik, bagaimana cara memanfaatkan limbah kemasan plastik (botol atau pun cangkir) sebagai tempat bertanam 
serta teknis bertanam dan panen. Kegiatan ini dilanjutkan dengan tanya jawab secara interaktif antara mitra dan pengusul. Kegiatan pada tahap ini dilaksanakan berupa penyuluhan yang diperjelas dengan foto atau video terkait dengan bertanam hidroponik. Kegiatan ini di dokumentasikan dalam bentuk video dan foto.

\section{Persiapan Alat dan Bahan}

Tahap ini warga yang telah dikelompokan berdasarkan RT dilibatkan dalam pengumpulan alat dan bahan yang akan digunakan, berupa: cutter dan gunting pemotong, kayu untuk pembuatan naungan hidroponik supaya tidak terpapar cahaya matahari secara langsung danbotol dan botol plastik bekas minumam volume 1,5 liter. Setiap warga yang mengumpulkan botol plastik bekas minuman akan diberikan insentif sebesar Rp 500,per botol sebagai upaya memotivasi mereka untuk menjaga kebersihan lingkungan.

\section{Pelaksanaan}

Tahap pelaksanaan berupa penanaman benih/penyemaian.
Kegiatan pembenihan dan pembuatan dosis nutrisi ini dilakukan langsung oleh penduduk dan didampingi oleh tim pengusul kegiatan. Benih disemai dengan menggunakan media sekam bakar yang berasal dari limbah panen padi dilanjutkan dengan perawatan tanaman yang telah disemai. Kegiatan ini didokumentasikan dalam bentuk foto danvideo. Selain itu, kegiatan ini juga dipublikasikan melalui media massa yang ada di Provonsi Sumatera Selatan.

\section{Pemeliharaan}

Tahap pemeliharaan ini berupa tanaman yang telah ditanam oleh masing-masing kelompok dipelihara oleh masing-masing kelompok yang bersangkutan. Pemeliharaan yang dilakukan meliputi penggantian dan penambahan media (unsur hara), pengendalian hama dan penyakit, penyulaman serta menjaga kondisi lingkungan yang optimal.

\section{Panen}

$\begin{array}{rrr}\text { Tahap } & \text { panen } & \text { sayuran } \\ \text { hidroponik } & \text { dilakukakn } & \text { bersama }\end{array}$
warga, perangkat Desa Sungsang III dan pemuka masyarakat. Kegiatan ini 
didokumentasikan dalam bentuk video dan foto.

\section{Monitoring dan Evaluasi}

Tahap monitoring dan evaluasi dilakukan oleh tim pengusul kegiatan terhadap kelompok masyarakat. Tahap ini tim pengusul menggali permasalahan-permasalahan yang dihadapi oleh mitra selama kegiatan berlangsung. Hal ini penting dilakukan dalam upaya untuk mencari solusi terhadap permasalahanpermasalahan tersebut. Evaluasi dilakukan terhadap tingkat keberhasilan penanaman. Kegiatan ini didokumentasikan dalam bentuk foto.

\section{Tanggapan/Respon}

Tahap ini bertujuan untuk melihat tanggapan/respon dari para peserta PKMS dilakukan penyebaran kuisioner/angket dengan isi pertanyaan pada Tabel 1. Masingmasing pertanyaan diberi bobot, sangat setuju diberi bobot 4 , setuju diberi bobot 3 , tidak setuju diberi bobot 2 dan sangat tidak setuju diberi bobot 1. Data yang diperoleh ditampilkan dalam bentuk grafik batang, lalu dianalisis secara diskriptif.

Tabel 1. Quisioner tanggapan peserta pelatihan hidroponik PKMS

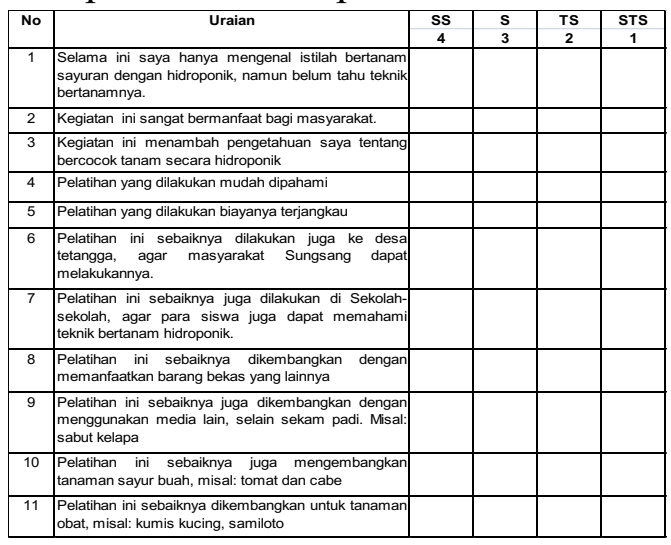

Keterangan: $\mathrm{SS}=$ sangat setuju, $\mathrm{S}=$ setuju, TS = tidak setuju dan STS = sangat tidak setuju.

\section{HASIL DAN PEMBAHASAN}

Hasil yang diperoleh dalam kegiatan PKM berdasarkan tahapantahapan kegiatan sebagai berikut:

\section{Survey}

Tahap survey lokasi melalui wawancara dengan masyarakat diperoleh bahwa masyarakat Desa Sungsang III umumnya memiliki tingkat ekonomi menengah ke bawah. Sebagian besar masyarakat bekerja sebagai nelayan dan mengolah produk-produk perikanan, misalnya membuat kerupuk udang, pempek udang, ebi (udang kering), ikan asin 
dan tekwan udang. Selain itu, sebagian masyarakat ada juga yang bekerja sebagai pedagang dan penarik becak/bentor. Masyarakat Desa Sungsang III sebagian besar memiliki tingkat pendidikan sampai Sekolah Menengah, sedangkan yang melanjutkan pendidikan ke perguruan tinggi masih sangat sedikit. Hal ini terjadi karena permasalahan biaya dan jarak yang cukup jauh untuk menjangkau perguruan tinggi. Sumber air bersih yang digunakan masyarakat lebih banyak bersumber dari alam yaitu dari air hujan dan air laut. Namun sumber air ini belum terjamin kebersihannya. Masyarakat ekonomi menengah ke atas hanya sebagian kecil masyarakat ekonomi menegah ke atas yaitu para pedagang pengumpul ikan nelayan memanfaatkan air minum isi ulang yang harganya cukup tinggi. Sementara itu, keberadaan instalasi pengolahan air bersih yaitu PDAM Tirta Betuah kurang dimanfaatkan oleh masyarakat karena biaya pemasangan instalasi dan biaya bulanan dianggap mahal. Sebagian besar kebutuhan pokok masyarakat didatangkan dari luar daerah, seperti dari Kota Palembang dan sekitarnya.
Khusus sayur-sayuran didatangkan dari Pasar Induk Kota Palembang dan Pulau Bangka sehingga harga sayuran tergolong cukup mahal karena biaya pengangkutan yang tinggi. Selama survei berlangsung tidak ditemukan masyarakat yang menjual sayuran dari hasil pertanian daerah tersebut.

\section{Sosialisasi}

Tahap sosialisasi dilakukan dengan cara mengumpulkan warga yang ada di Desa Sungsang III di Balai Desa (Gambar 2). Sosialisasi ini bertujuan memberdayakan masyarakat agar lebih baik. Apriliyanto (2017) melakukan pemberdayaan masyarakat santri melalui kegiatan pembuatan pestisida hayati, kegiatan ini bertujuan agar para masyarakat santri dalam pemenuhan kebutuhan pangan melalui budidaya tanaman organik yang bebas dari bahan kimia, yaitu dengan pembuatan pestisida organik yang berasal dari tumbuhan.

Kegiatan sosialisasi ini dihadiri oleh masyarakat setempat, kelompok Ibu-Ibu PKK, remaja yang tergabung dalam Karang Taruna serta siswasiswi sekolah menengah. Kegiatan sosialisasi ini disambut baik oleh 
masyarakat karena sebagian besar mereka belum mengenal sistem bercocok tanam secara hidroponik.
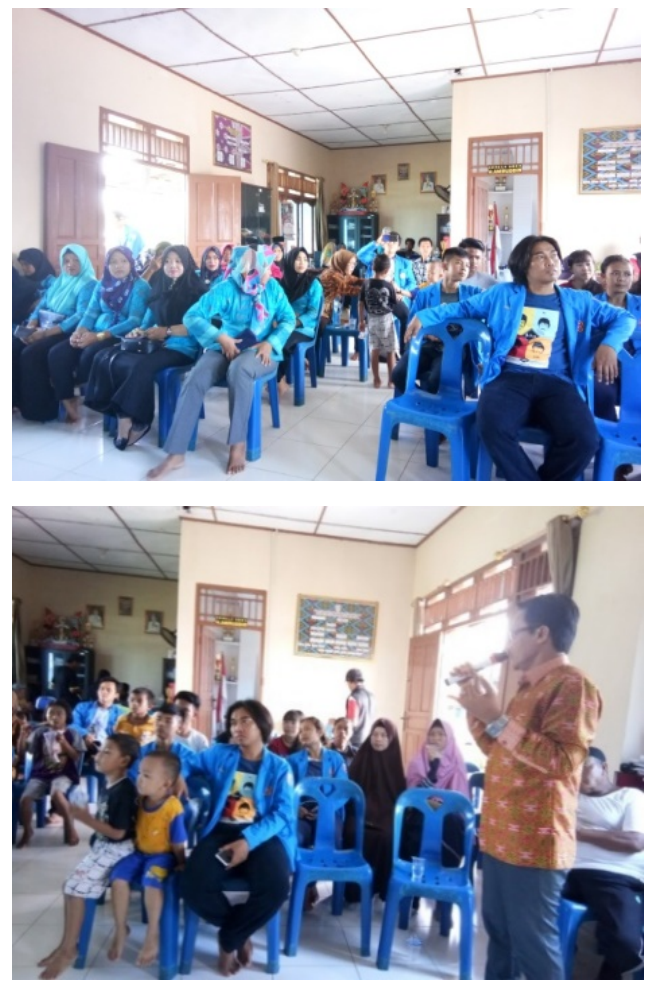

Gambar 2. Kegiatan sosialisasi PKMS hidroponik di Desa Sungsang III.

Antusias masyarakat ditunjukkan dengan tanya jawab secara interaktif antara masyarakat dan narasumber. Pertanyaanpertanyaan yang muncul dari masyarakat bermacam-macam, seperti mengenai media tanam, nutrisi, tempat penanaman, biaya dan keuntungan-keuntungan. Narasumber memberikan jawaban serta contohcontoh yang relevan sesuai keadaan yang sebenarnya. Hasilnya masyarakat merasa tertarik untuk mencoba bercocok tanam secara hidroponik.

Mulyadi (2013) mengemukakan bahwa pemberdayaan masyarakat lokal dalam pembangunan kehutanan dapat dilakukan dengan cara merubah sikap masyarakat untuk menempatkan diri sebagai pelaku pembangunan serta melakukan gerakan sosial dalam pemberdayaan masyarakat lokal. Pemberdayaan dapat dilakukan diantaranya dengan kegiatan PKM (melalui program penanaman tanaman secara hidroponik, khususnya tanaman bernilai ekonomis (sayur-sayuran), dengan yang memanfaatkan limbah plastik. Bercocok tanam dengan hidroponik menguntungkan karena tidak memerlukan area pertanaman yang luas dan sistem pemeliharaan yang lebih mudah serta hasilnya sudah teruji lebih melimpah dan berkualitas. Putriyandari et al. (2018) melakukan PKM bagi ibu-ibu PKK di Cimahi Selatan melalui bertanam hidroponik. Hasil PKM menunjukkan ibu-ibu PKK menjadi lebih produktif dan mampu menghasilkan tanaman sehat dan 
segar. Saputra et al. (2018) melakukan PKM berupa bertanam hidroponik ke masyarakat. Kegiatan PKM yang dilakukan telah berhasil membentuk Desa Wisata hidroponik. Bukti keberhasilan tersebut banyak masyarkat sekitar berkunjung ke pusat hidroponik untuk membeli produk sayuran atau peralatan hidroponik serta sekaligus belajar teknik menanam hidroponik.

\section{Persiapan Peralatan dan Bahan}

Tahap persiapan peralatan dan bahan dilakukan di Kampus Universitas PGRI Palembang dan di Desa Sungsang III (Gambar 3).

Persiapan peralatan dan bahan di Kampus Universitas PGRI Palembang berupa persiapan wadah penanaman berupa botol plastik minuman volume 1,5 liter. Selain itu juga, dipersiapkan media tanam berupa sekam padi yang telah dibakar, bibit tanaman sayur berupa pakcoy (sawi sendok), bayam merah dan kangkung serta nutrisi yang telah dilarutkan dalam air.

Pembuatan tempat tanaman hidroponik ini bertujuan dalam rangka mengatasi pencemaran lingkungan di Desa Sungsang III, sekaligus mengenakan teknologi tepat guna bagi masyarakat, sejalan dengan kegiatan tersebut Sulistywati et al. (2019) melakukan PKM bertanam dengan menggunakan teknik hidroponik memanfaatkan botol bekas di Gunung Kidul yang wilayahnya sulit air dimana pertaniannya berupa tadah hujan. Hasilnya masyarakat tersebut dapat bercocok tanam dan terbantukan secara ekonomi.
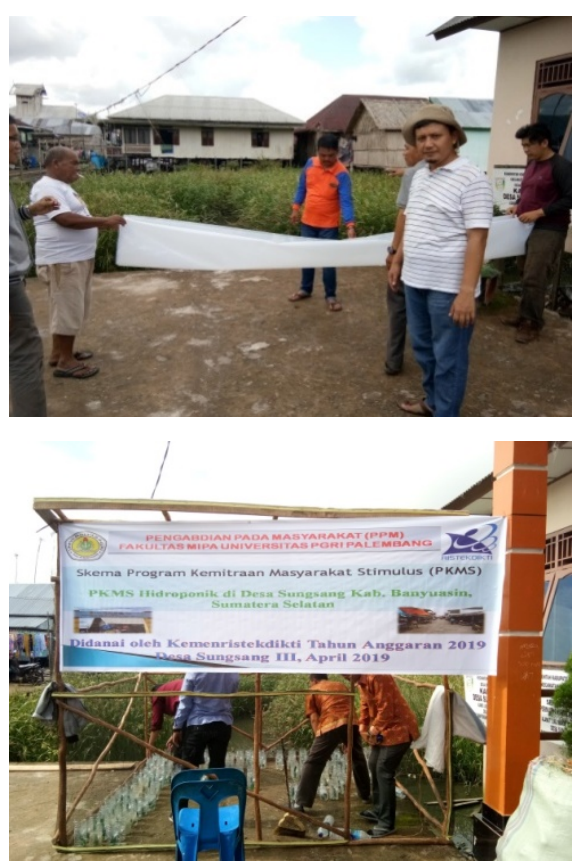

Gambar 3. Persiapan rumah plastik dalam kegiatan PKMS hidroponik.

Pemenuhan akan kebutuhan zat makanan bagi tanaman yang ditanam secara hidroponik harus tetap bisa 
terpenuhi. Pupuk yang diberikan harus mengandung semua unsur hara yang dibutuhkan tanaman. Unsurunsur yang selalu ada didalam tanaman yaitu; $\mathrm{C}, \mathrm{H}, \mathrm{O}, \mathrm{N}, \mathrm{P}, \mathrm{S}, \mathrm{K}$, $\mathrm{Ca}, \mathrm{Mg}, \mathrm{Fe}$, sedangkan unsur-unsur seperti $\mathrm{Zn}, \mathrm{Mn}, \mathrm{Cu}, \mathrm{B}$, Mo ditemukan dalam jumlah yang sangat kecil. Unsur-unsur lainnya seperti $\mathrm{Si}, \mathrm{Al}$, $\mathrm{Cl}$, pun ada dalam jumlah yang sangat kecil. Unsur-unsur $\mathrm{C}, \mathrm{H}, \mathrm{O}, \mathrm{N}, \mathrm{S}, \mathrm{P}$, $\mathrm{K}, \mathrm{Ca}, \mathrm{Mg}$ dibutuhkan dalam jumlah yang agak besar. Kesembilan unsurunsur ini disebut unsur makro sedang sisanya disebut unsur mikro (Ashari,1995; Dwidjoseputro, 1992; Epsteins, 1972). Unsur makro dan mikro harus mempunyai nilai yang tepat karena kedua saling menunjang terhadap pertumbuhan tanaman (Triyono, dan Istiyastuti, 1996). Hamidah (2017) menjelaskan dalam kegiatan PKM tentang pupuk cair yang berasal dari urine sapi dan zat pengatur tumbuh. Hasilnya menunjukkan pertumbuhan yang lebih baik pada tanaman

Persiapan peralatan dan bahan di lapangan (Desa Sungsang III) pembuatan rumah plastik dari kayu gelam dengan atap plastik UV. Selain itu juga disiapkan berbagai kelengkapan lain seperti baskom, ember plastik, pisau cutter, gunting dan alat penyiram tanaman. Persiapan alat dan bahan di lapangan ini dibantu oleh masyarakat setempat atas arahan dan bimbingan pelaksana PKM.

\section{Pelaksanaan}

Tahap pelaksanaan kegiatan ini dilakukan dalam bentuk penanaman benih sayuran berupa pakcoy, bayam merah dan kangkung (Gambar 4). Kegiatan ini masyarakat diperkenalkan dengan berbagai macam instrumen sederhana bertanam hidroponik, seperti modifikasi botol plastik untuk wadah media tanam, pembuatan media tanam berupa sekam padi yang dibakar dan pembuatan larutan nutrisi AB-mix. Nutrisi ini mempunyai peranan yang sangat penting daam pertumbuhan dan kesuburan tanaman hidroponik. 

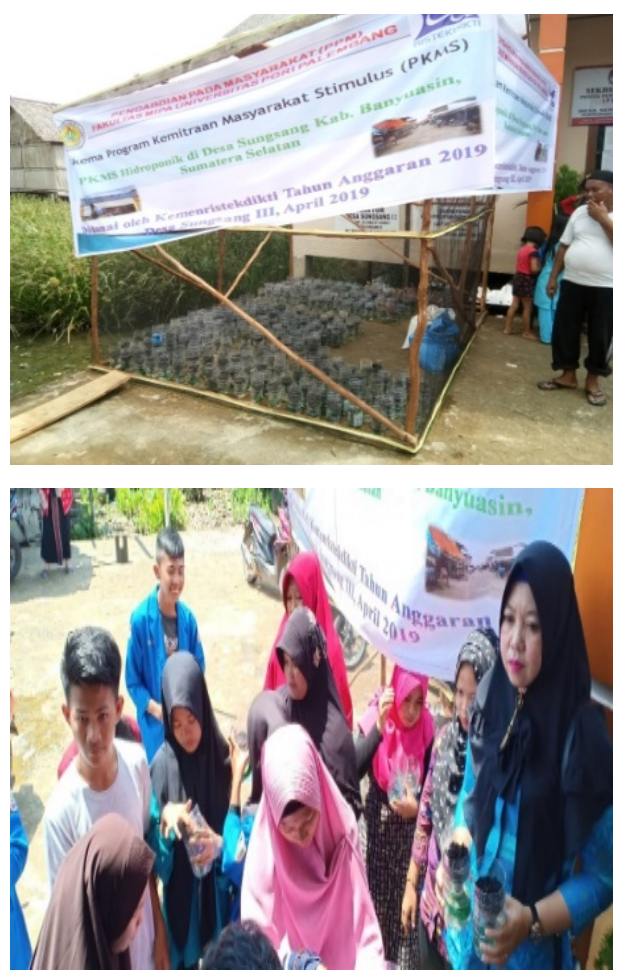

Gambar 4. Kegiatan penanaman tanaman sayur secara hidroponik

Dwidjoseputro

berpendapat bahwa tanaman tumbuh dengan subur apabila unsur yang dibutuhkannya cukup tersedia, unsur itu ada dalam bentuk yang sesuai untuk diserap tanaman. Bercocok tanam dengan teknik hidroponik memberikan banyak keuntungan diantaranya adalah tidak memerlukan lahan pertanian yang luas (tidak memerlukan media tanah), sistem pemeliharaannya lebih mudah, hasilnya lebih besar, ramah lingkungan, bebas pestisida, kualitas tanaman lebih baik karena terhindar dari hama/penyakit tanaman dan kebersihan serta komposisi nutrisi dalam tanam dapat dijaga dan dikontrol (Pipi et al. 2017; Triana et al. 2017; Handayani et al. 2018). Menurut Septia et al. (2018) bahwa konsep hidroponik yang memanfaatkan lahan perkarangan sempit dapat menjadi upaya pemberdayaan ibu rumah tangga dalam peningkatan usaha produktif. Pertanian sayuran secara hidroponik khusunya di Kota Padang layak untuk dilakukan karena memberikan keuntungan yang cukup besar bagi petani (Triana et al. 2017).

Penanaman dilakukan sepenuhnya oleh masyarakat dengan didampingi pelaksana kegiatan PPM. Masyarakat cukup antusias untuk ikut menanam, mulai dari orang tua, remaja sampai anak-anak ikut terlibat dalam penanaman. Melalui kegiatan ini masyarakat secara langsung diedukasi dalam proses penanaman dan pemeliharaan tanaman hidroponik.

5. Pemeliharaan

Tahap pemeliharaan tanaman sayur hidroponik dilakukan dengan cara penggantian dan 
penambahanmedia (unsur hara), pengendalian hama dan penyakit, penyulaman serta menjaga kondisi lingkungan yang optimal. Pemeliharaan ini sepenuhnya dilakukan oleh masyarakat yang telah ditunjuk untuk membantu tim pelaksana PPM. Hal ini dilakukan agar masyarakat dapat mempraktekkan secara langsung cara memelihara tanaman hidroponik sekagius mereka dapat memantau perkembangan tanaman.

Pemeliharaan dilakukan selama lebih kurang lima minggu.

\section{Panen}

Tahap panen dilakukan sebanyak dua tahap. Tahap pertama dilakukan panen bayam merah setelah penanaman selama dua minggu. Tahap kedua dilakukan panen kangkung, pakcoy dan sisa bayam merah setelah penanaman selama lima minggu. Kegiatan panen ini dilakukan sepenuhnya oleh masyarakat dengan didampingi oleh pelaksana PPM (Gambar 5). Masyarakat sangat antusias dalam mengikuti panen dimana hasil panen seluruhnya diberikan kepada masyarakat.

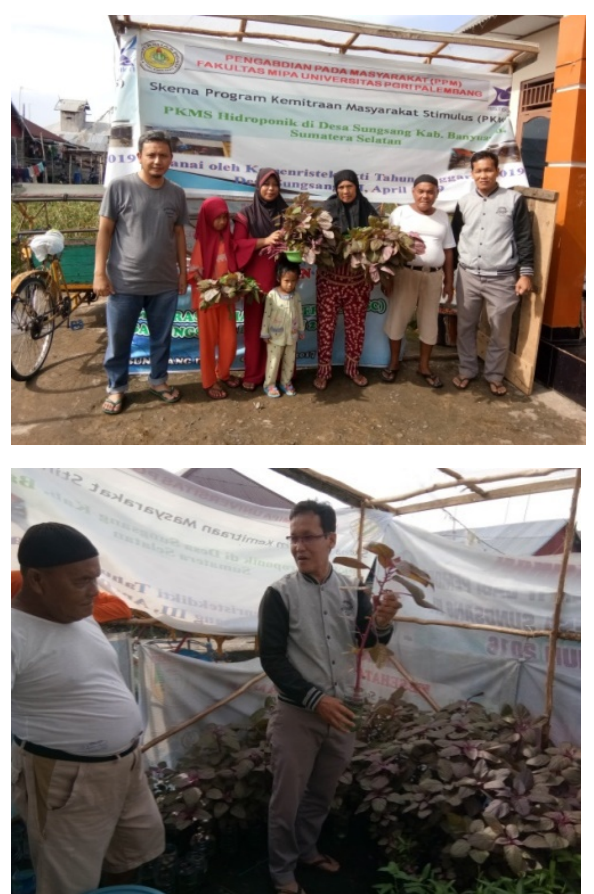

Gambar 5. Kegiatan panen tanaman sayuran hidroponik.

\section{Monitoring dan Evaluasi}

Tahap monitoring dan evaluasi dilakukan oleh pelaksana PKM selama kegiatan, mulai dari survei sampai dengan panen. Berdasarkan hasil monitoring dan evaluasi diperoleh bahwa masyarakat sulit memperoleh media tanam sekam padi yang sudah dibakar, bibit sayuran dan nutrisi AAB-mix. Untuk itu pelaksana PKM memberikan solusi dan arahan dimana bahan-bahan tersebut bisa diperoleh serta memfasilitasi untuk memperoleh bahan-bahan tersebut. Wadah 
penanaman berupa botol plastik yang dimodifikasi pada dasarnya mereka telah dapat membuat sendiri, namun mereka kesulitan untuk memperoleh kain planel sebagai penyerap nutrisi. Untuk itu pelaksana PKM telah memberikan arahan dan memfasilitasi untuk memperoleh kain planel tersebut.Tim pelaksana PKM juga memfasilitasi dengan memberikan media tanam sekam padi bakar, nutrisi AB-mix dan bibit tanaman untuk masyarakat mencoba melanjutkan menanam tanaman sayur sehingga saatnya nanti mereka dapat melaksanakan sendiri.

Pelaksana PKM juga melakukan pemantauan selama masa pemeliharaan tanaman setiap 10 hari. Hasil pemantauan menunjukkan bahwa tanaman bayam merah paling cocok ditanam di daerah ini, terbukti tanaman ini sangat subur dan sudah dapat dipanen setelah dua minggu. Kangkung dan pakcoy dan kangkung kurang cocok ditanam di daerah ini karena lambat tumbuh dan kerdil. Hal ini dapat disebabkan karena tanaman ini tidak cocok ditanam di lingkungan wilayah pesisir dengan cuaca yang panas. Bayam merah dapat direkomendasikan untuk ditanam di
Desa Sungsang III sedangkan pakcoy dan kangkung kurang cocok. Untuk itu pelaksana PKM menyarankan untuk dicoba ditanam jenis tanaman sayur lainnya seperti selada, caisin dan seledri serta jenis sayuran buah seperti tomat dan cabe.

\section{Tanggapan/Respon}

Tahapan dari tanggapan/respon dari peserta berupa isian quisioner (Tabel 1), ditampikan dalam bentuk gambar 6 .

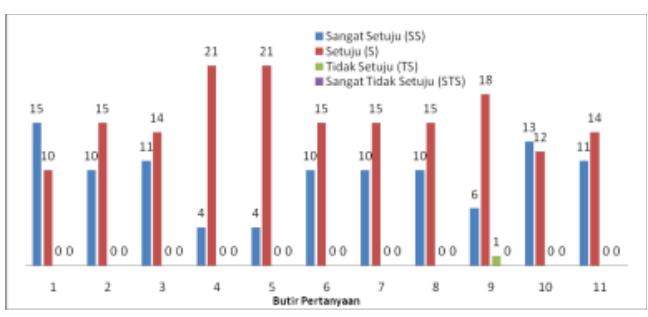

Gambar 6 Respon Peserta Pelatihan

Hidroponik

Gambar 6 terlihat bahwa untuk pertanyaan nomor 1 "Selama ini saya hanya mengenal istilah bertanam sayuran dengan hidroponik, namun belum tahu teknik bertanamnya". Para peserta mayoritas sebanyak 15 orang menjawab sangat setuju, sisanya 10 orang menjawab setujuh dan tidak ada yang menjawab tidak 
setuju dan sangat tidak setuju. Ini menunjukkan bahwa memang masyarakat Sungsang III hanya mengenal istilah hidroponik, namun dalam pelaksanaan cara bertanam dengan hidroponik, ditambah lagi dengan aplikasi memanfaatkan limbah plastik botol plastik sebagai tempat bertanam belum mereka kenal, sebagain meraka hanya mengenal teknik bertanam hidroponik tersebut dengan menggunakan pipa, yang biayanya relatif mahal.

Pertanyaan nomor 2 "kegiatan ini sangat bermanfaat bagi masyarakat", mayoritas responden sebanyak 15 orang menjawab setuju dan sangat setuju 10 orang. Begitu juga untuk pertanyaan nomor 3 "kegiatan ini menambah pengetahuan saya tentang bercocok tanam secara hidroponik", mayoritas masyarakat menjawab setuju sebanyak 14 orang, sangat setuju ada 11 orang dan tidak ada responden yang tidak setujuh ataupun sangat tidak setuju. Ini menunjukkan bahwa memang kegiatan ini bermanfaat dan menambah pengetahuan bagi masyarakat Desa Sungsang III.
Pertanyaan nomor 4 dan 5 tentang pelatihan, dimana pertanyaan nomor 4 "Pelatihan yang dilakukan mudah dipahami”, mayoritas responden menjawab setuju sebanyak 21 orang dan 4 orang yang menjawab sangat setuju. Ini menunjukan pelatihan yang dilakukan memang mudah dipahami, sehingga terlihat ada peningkatan pengetahuan dan keterampilan masyarakat dalam bercocok tanam menggunakan metode hidroponik dibandingkan sebelum dilakukan kegiatan PKM ini. Pertanyaan nomor 5 "Pelatihan yang dilakukan biayanya terjangkau", mayoritas responden menjawab setuju sebanyak 21 orang dan sisanya 4 orang menjawab sangat setujuh. Ini menunjukkan bahwa memang pelatihan yang dilakukan biayanya terjangkau bagi masyarakat.

Pertanyaan nomor 6 hingga nomor 11 terkait dengan perlunya dilakukan didesa yang lain dan perlunya pengembangan dengan memanfaatan bahan bekas yang lain dan penggunaan media lain selain sekam padi serta pengembangan tanaman buah atau pun tanaman obat. Mayoritas responden menjawab sangat setuju dan setuju. Ini 
menunjukkan bahwa respon para peserta pelatihan ingin kegiatan ini perlu dikembangkan dengan memanfaatkan limbah plastik yang lain, misal: galon air atau pun tempat tampungan air yang lebih besar. Selain itu masyarakat ingin medianya digunakan media tanam yang lain, misal sabut kelapa, dimana potensi sabut kelapa di desa tetangganya yaitu kampung Bugis penghasil kelapa. Disamping itu juga para peserta pelatihan menunjukkan ingin dikembangkan jenis tanaman yang lain selain sayuran, misalnya buahbuahan maupun tanaman obat.

\section{SIMPULAN}

Berdasarkan hasil dari kegiatan ini dapat ditarik beberapa kesimpulan sebagai berikut:

1. Kegiatan ini telah mampu menambah pengetahuan dan pemahaman masyarakat Desa Sungsang III terhadap teknik sederhana bertanam secara hidroponik.

2. Kegiatan ini telah membantu pemerintah Desa Sungsang III dalam hal membangun kesadaran masyarakat untuk memanfaatkan limbah plastik dan sekaligus mengedukasi masyarakat tentang bertanam secara hidroponik.

\section{UCAPAN TERIMAKASIH}

Penulis mengucapkan terima kasih kepada: Kementerian Riset Teknologi dan Pendidikan Tinggi yang telah mendanai kegiatan ini skema Pengabdian Kepada Masyarakat Stimulus (PKMS).

\section{DAFTAR PUSTAKA}

Apriliyanto, E. (2017).

Pemberdayaan Santri Melalui

Pelatihan Pembuatan Pestisida

Nabati. Pengabdian Dan

Pemberdayaan Masyarakat, 1(2).

Eddy, S., Iskandar, I., Ridho, M. R., \& Mulyana, A. (2017). Land cover changes in the air telang protected forest, South Sumatra, Indonesia (1989-2013). Biodiversitas, 18(4), 15381545. https://doi.org/10.13057/biodiv/ d180432

Eddy, S., \& Mutiara, D. (2018).

Dinamika Tutupan Lahan Kawasan Hutan Lindung Air Telang Menggunakan Teknik Overlay Multitemporal. 
Syaiful Eddy, Andi Arif Setiawan, Dian Mutiara/Aksiologiya: Jurnal Pengabdian Kepada Masyarakat. Vol. 6, No. 1, Februari 2022 Hal 73 - 90

Sainmatika: Jurnal Ilmiah

Matematika Dan Ilmu

Pengetahuan Alam, 15(2), 96.

https://doi.org/10.31851/sainma

tika.v15i2.2179

Eddy, S., Ridho, M. R., Iskandar, I., \& Mulyana, A. (2019). Species composition and structure of degraded mangrove vegetation in the Air Telang Protected Forest, South Sumatra, Indonesia. Biodiversitas, 20(8), 2119-2127.

https://doi.org/10.13057/biodiv/ d200804

Hamidah, Mahdalena, \& Roofig, A. (2017). Jurnal Abdimas

Mahakam Jurnal Abdimas

Mahakam. Jurnal Abdimas

Mahakam, 1(2).

Kusomo, R.A.B., Charina, A. and

Sadeli, A. H. (2020). An

enhancement effort of

additional value organic

vegetable products in cibodas

village, lembang sub-district,

bandung barat district.

Dharmakarya: Jurnal Aplikasi

Ipteks Untuk Masyarakat, 7(1),

61-64.

Pardian, P., Rasmikayati, E.,

Djuwendah, E. dan Saefudin, B.
R. (2017). Persepsi dan minat

petani muda dalam budidaya sayuran. Dharmakarya: Jurnal Aplikasi Ipteks Untuk Masyarakat, 6(3), 163-166.

Putriyandari, R., Yuliyana, W., \&

Rahayu, Y. S. (2018).

Pemberdayaan Peran Ibu

Rumah Tangga dalam

Meminimalisir Belanja Rumah

Tangga Konsumen Melalui

Budidaya Tanaman Hidroponik.

Abdimasi BSI, 1(2), 268-280.

Saleh, E., Umar, H. M., Priatna, S. J., \& Sanjaya, R. (2019). Adaptasi

Pola Genangan Air Rawa Lebak

Dengan Budidaya Tanaman

Padi Mengambang Di Desa

Pelabuhan Dalam, Kabupaten

Ogan Ilir. Jurnal Pengabdian

Sriwijaya, 7(1), 703-709.

https://doi.org/10.37061/jps.v7i

1.7543

Saputra, H., Rudianto, R., Setiawan,

D., \& Nugroho, R. A. (2018).

Desa Wisata Hidroponik

Sebagai Upaya Pemberdayaan

Masyarakat Desa Sidomulyo

Kecamatan Anggana Kabupaten

Kutai Kartanegara. Jurnal

Pengabdian Kepada

Masyarakat, 24(1), 587. 
Syaiful Eddy, Andi Arif Setiawan, Dian Mutiara/Aksiologiya: Jurnal Pengabdian Kepada Masyarakat. Vol. 6, No. 1, Februari 2022 Hal 73 - 90

https://doi.org/10.24114/jpkm.v

$24 \mathrm{i} 1.9656$ https://ojs.unm.ac.id/semnaslpm /article/view/11665

Setiawan, A. A., Budianta, D.,

Suheryanto, \& Priadi, D. P.

(2018). Contents of Heavy

Metal in Soil and Water at

Stockpile Coal (Case Study

Kertapati Palembang City

Indonesian). Pollution

Research, 37(2), 301-306.

Siaga, E., \& Lakitan, B. (2021).

Pembibitan Padi dan Budidaya

Sawi Hijau Sistem Terapung

sebagai Alternatif Budidaya

Tanaman Selama Periode Banjir

di Lahan Rawa Lebak,

Pemulutan, Sumatera Selatan.

Abdimas Unwahas, 6(1), 1-6.

Sulistywati, Maulana, M., Tentama,

F., Asti, S., \& Sukesi, T. W.

(2019). Pendampingan

pembuatan sistem hidroponik

dan pengolahan sampah

organik. Jurnal Pengabdian

Dan Pemberdayaan

Masyarakat, 3(1), 77-82.

Yunus, S. R., Rusli, M. A., \& Tawil, M. (2019). Respons guru SMPN

1 Bantaeng terhadap workshop

budidaya tanaman sistem

hidroponik. Seminar Nasional

Pengabdian ..., 522-525. 